\title{
Synthesis of the New 2-[6-Nitro-2-Benzothiazolylazo]-4-Hydroxy Benzoic Acid Organic Reagent for Spectrophotometric Determination of Copper(II)
}

\section{Aqeel Mahdi Jreo*}

Department of Chemistry, College of Education, Kufa University, Iraq

\begin{abstract}
A new 2-[6-Nitro-2-benzothiazolylazo]-4-hydroxy benzoic acid ( $\mathrm{NO}_{2} \mathrm{BTAHB}$ ) organic reagent was synthesized. A sensitive and selective spectrophotometric method was proposed for the rapid determination of $\mathrm{Cu}$ (II) using $\left(\mathrm{NO}_{2} \mathrm{BTAHB}\right)$ reagent. The reaction between $\mathrm{Cu}(\mathrm{II})$ and $\left(\mathrm{NO}_{2} \mathrm{BTAHB}\right)$ reagent is instantaneous at $\mathrm{pH}=6.0$ and the absorbance remains stable for over $24 \mathrm{hrs}$. The Method allows for the determination of $\mathrm{Cu}(\mathrm{II})$ over the range (0.1-6.0) $\mu \mathrm{g} \cdot \mathrm{ml}^{-1}$, with molar absorptivity of $\left(7.45 \times 10^{+3}\right) \mathrm{l} \cdot \mathrm{mol}^{-1} \cdot \mathrm{cm}^{-1}$ and a detection limit of $0.0245 \mu \mathrm{g} \cdot \mathrm{ml}^{-1}$. Recovery and relative error values of precision and accuracy of method were found to be R.S.D $=1.7 \%$, Re $=98.6 \%$, and Erel=-1.4\%. The properties of complex was studied and show; $(\mathrm{M}: \mathrm{R})$ ratio was $1: 2$ at $\mathrm{pH}=6.0$, and the stability constant of $7.796 \times 10^{+9}$ $\mathrm{L}^{2} \cdot \mathrm{mol}^{-2}$. The interferences of ions $\left(\mathrm{Ni}^{2+}, \mathrm{CrO}^{2-}, \mathrm{Ca}^{2+}, \mathrm{pb}^{2+}, \mathrm{Cu}^{+2}, \mathrm{WO}_{4}^{-2}, \mathrm{MO}_{4}^{-2}, \mathrm{Co}^{2+}, \mathrm{Mg}^{2+}, \mathrm{Cd}^{2+}, \mathrm{Ba}^{2+}, \mathrm{Bi}^{3+}\right)$ and masking agents effect on absorbance were studied.
\end{abstract}

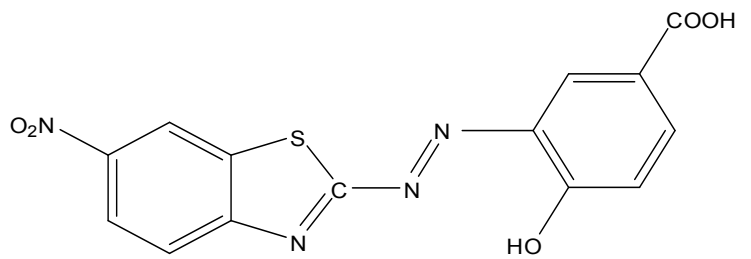

Keywords: Ligand; Ion; $\mathrm{Cu}$; Determination; Reagent

\section{Introduction}

Copper plays a different role in the human body. It is an essential nutrient or a toxic element for human beings, depending on the concentration level $[1,2]$. Some chromogenic reagents have been used in spectrophotometric methods of determination of copper such as Acetophenone-p-chlorophenylthiosemicarbazone [3], Hydrazinecarboxymide2-[(2-hydroxyphenyl) methylene (HC22HPM) [4], Piperazine [5], Chloro(phenyl) glyoxime [6], sodium(I) diethyldithiocarbamate [7], brilliant cresyl blue(BCB) [8], cefixime [9], 4-(6-Bromobenzothiazolylazo)Orcinol [10], 3-(2'-thiazolylazo)-2,6-diaminopyridine [11], 2-[2-(4-methylbenzothiazolyl)azo]-5-dimethylaminobenzoic acid [12], 2[2-(5-bromo thiazolyl) azo]-4-methoxy phenol [13], and 2,6-dichlorophenolindophenol [14]. Thiazolylazo compounds have attracted the attention, as they are sensitive chromogenic reagents in addition to being important complexing agents. These dyes are useful in spectrophotometric determinations due to their good selectivity over a wide range of $\mathrm{pH}$ and they are relatively easy to synthesize and purified [15]. In this paper, a new ( $\left.\mathrm{NO}_{2} \mathrm{BTAHB}\right)$ chromogenic reagent was synthesized for spectrophotometric determination of $\mathrm{Cu}(\mathrm{II})$.

\section{Reagents}

All reagents were of analytical grade. Freshly distilled and deionized water was used for solutions preparations

\section{Preparation of reagent [16]}

To a mixture of $\{(4.3 \mathrm{gm}$ of para nitro aniline and $3.8 \mathrm{gm}$ of ammonium thiacyanate) in $70 \mathrm{ml}$ glacial acetic acid\}, was added drop by drop from burette $(1.2 \mathrm{ml} \mathrm{Br}+15 \mathrm{ml}$ glacial acetic acid) keeping at temperature $>10^{\circ} \mathrm{C}$. After 15 minutes alkaline solution was added to precipitate the thiazole derivative, $1.145 \mathrm{gm}$ of thiazole and in $50 \mathrm{ml}$ glacial acetic acid then add $(5 \mathrm{ml}$ conc. $\mathrm{HCl}+25 \mathrm{ml}$ water $)$ to the solution. After that drop by drop from burette a solution $(0.690 \mathrm{gm} \mathrm{NaNO}$ $\left.+50 \mathrm{ml} \mathrm{H} \mathrm{H}_{2} \mathrm{O}\right)$ with stirring at $0-5^{\circ} \mathrm{C}$ to diazonium salt, then $(0.1 .390$ gm of parahydroxy benzoic acid $+50 \mathrm{ml}$ ethanol) is added to diazonium salt and 2-[6-nitro-2-benzothiazolyl azo]-4- hydroxy benzoic acid $\left(\mathrm{NO}_{2} \mathrm{BTAHB}\right)$ organic reagent was formed.

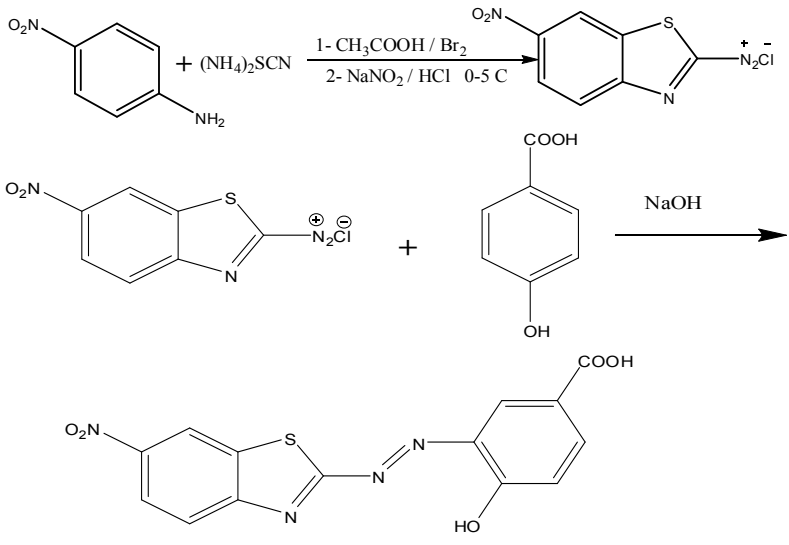

*Corresponding author: Aqeel Mahdi Jreo, Department of Chemistry, College of Education, Kufa University, Iraq, Tel: +96433 340952; E-mail: aqeel-me79@gmail.com

Received: March 20, 2015; Accepted: March 28, 2015; Published April 06, 2015

Citation: Jreo AM (2015) Synthesis of the New 2-[6-Nitro-2-Benzothiazolylazo]-4Hydroxy Benzoic Acid Organic Reagent for Spectrophotometric Determination of Copper(II). Biochem Anal Biochem 4: 167. doi:10.4172/2161-1009.1000167

Copyright: (c) 2015 Jreo AM. This is an open-access article distributed under the terms of the Creative Commons Attribution License, which permits unrestricted use, distribution, and reproduction in any medium, provided the original author and source are credited. 


\section{Standard solutions}

Stock $\mathrm{Cu}(\mathrm{II})$ solution; A solution of $\mathrm{Cu}(\mathrm{II})\left(100 \mu \mathrm{g} \cdot \mathrm{ml}^{-1}\right)$ was prepared by dissolving $(0.0392)$ gm of $\mathrm{CuSO}_{4} .5 \mathrm{H}_{2} \mathrm{O}$ in $(100 \mathrm{ml})$ distilled water. Other standard solutions of $\mathrm{Cu}(\mathrm{II})$ were prepared by dilution of stock solution with distilled water. $-1 \times 10^{-3} \mathrm{M}\left(\mathrm{NO}_{2} \mathrm{BTAHB}\right)$ standard solution was prepared by dissolving $(0.088) \mathrm{g}$ in $250 \mathrm{ml}$ of absolute ethanol. -Buffer solution [17] $(\mathrm{pH}=6.0)$ was prepared by mixing 12.63 $\mathrm{ml}$ of $(0.2) \mathrm{M} \mathrm{Na}_{2} \mathrm{HPO}_{4}$ (which was prepared by dissolving $2.83 \mathrm{gm}$ in $100 \mathrm{ml}$ distilled water) and $7.37 \mathrm{ml}$ of (0.1) M Citric acid (which was prepared by dissolving $1.92 \mathrm{gm}$ in $100 \mathrm{ml}$ distilled water).

\section{Apparatus}

Spectrophotometric measurements were made with a Shimadzo (UV-Vis.) scientific equipment with $1.0 \mathrm{~cm}$ cell for plot spectra. The pD-303. Spectrophotometer, APEL Japan, was used in the other measurements. The pH-meter, 720 WTW, Germany and FT-IR Spectrophotometer shimadzo, Japan, were used in this work.

\section{Procedure}

To an aliquot containing $\leq 10 \mu \mathrm{g} \cdot \mathrm{ml}^{-1}$ of $\mathrm{Cu}(\mathrm{II})$ in a $10 \mathrm{ml}$ volumetric flask, was added $2 \mathrm{ml}$ of buffer solution, and $3.5 \mathrm{ml}$ of $\left(2 \times 10^{-4} \mathrm{M}\right)$ of $\left(\mathrm{NO}_{2} \mathrm{BTAHB}\right)$ solution. The solution was diluted to the mark with distilled water, and absorbance was measured at $25^{\circ} \mathrm{C}$ and wave length of $618 \mathrm{~nm}$ against the reagent solution as a blank solution prepared under the same conditions.

\section{Results and Discussion}

\section{FT-IR spectrum of reagent ( $\left.\mathrm{NO}_{2} \mathrm{BTAHB}\right)$}

The following table shows the main vibration frequencies of main absorption bands characteristic of reagent (Table 1 and Figure 1).

\section{Properties of the ( $\left.\mathrm{NO}_{2} \mathrm{BTAHB}\right)$}

$\left(\mathrm{NO}_{2} \mathrm{BTAHB}\right)$ reagent is slightly soluble in water, red powder, orange and stable solution for suitable period time, but in basic medium $\mathrm{pH} \geq 8.0$ the solution being pink. Such behavior may be interpreted by the following equilibria (Figure 2).

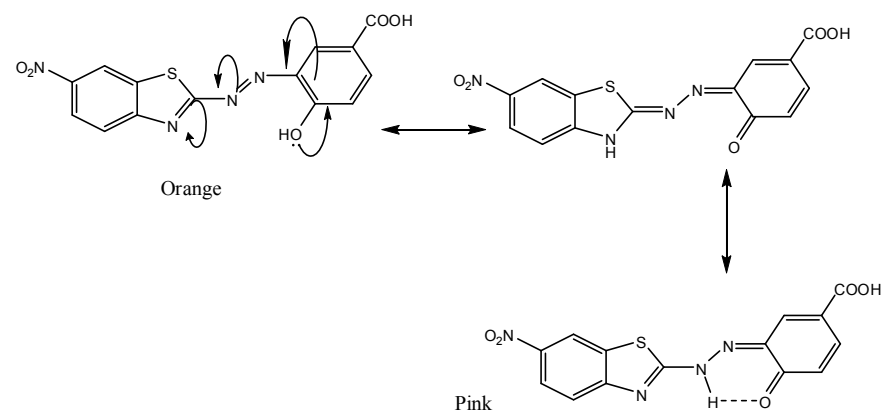

Study of $\mathrm{Cu}(\mathrm{II})-\left(\mathrm{NO}_{2} \mathrm{BTAHB}\right)$ complex

Absorption spectra: a-Ultra violet-visible absorption spectra of ( $\left.\mathrm{NO}_{2} \mathrm{BTAHB}\right)$ reagent, and $\mathrm{Cu}(\mathrm{II})-\left(\mathrm{NO}_{2} \mathrm{BTAHB}\right)$ complex solution are shown in Figure 3. The reagent showed an absorption maximum at 439 $\mathrm{nm}$, and the complex at $618 \mathrm{~nm}$.

\section{FT-IR spectrum of $\mathrm{Cu}-\left(\mathrm{NO}_{2} \mathrm{BTAHB}\right)$ complex}

Changing in intensities, shift in peaks positions, and fission in azo peak were seen which indicate to formation of complex as in following Figure 4.

\section{Effect of pH}

The effect of $\mathrm{pH}$ was studied over the rang (2-9) adjusted by means of dilute $\mathrm{HCl}$ and $\mathrm{NaOH}$ solution. Figure 5 shows the relationship between absorbance and $\mathrm{pH}$, where the maximum absorbance obtained in the range of $\mathrm{pH}=(4.0-7.5)$. At $7.5<\mathrm{pH}<4.0$ a decrease in absorbance. Therefore, the optimum $\mathrm{pH}$ was 6.0 , where the

absorbance was maximum and constant.

\section{Effect of Time}

The stability of complex was studied from (0-120) min with 5 minutes intervals up to $24 \mathrm{hrs}$. The maximum absorbance was reached at 10 minutes Figure 6 after that the absorbance remains constant.

\section{Effect of Temperature}

The effect of temperature on absorbance of complex was studied; the study was performed at temperature between $(5-80)^{\circ} \mathrm{C}$. Figure 7 show the maximum absorbance obtained at temperature range $(15-40)^{\circ} \mathrm{C}$ which was regarded as a proper temperature of complex formation. At temperatures higher than $40^{\circ} \mathrm{C}$ the absorbance decrease due to dissociation of complex gradually.

\section{Determination of Stoichiometry and Formation Con- stant}

The composing of complex was studied by jobs method of continuous variations and mole ratio method [18]. Figures 8 and 9 both methods indicate that the ratio of metal ion to reagent molecules $(\mathrm{M}: \mathrm{L})$ was (1:2) at $\mathrm{pH}=6.0$.

The formation constant calculated by applied procedure, was found to be $\left(7.796 \times 10^{+9}\right) \mathrm{L}^{2}$. $\mathrm{mol}^{-2}$

\section{Suggestion of Structural Formula of $\mathrm{Cu}(\mathrm{II})-\left(\mathrm{NO}_{2} \mathrm{BTAHB}\right)$ Complex}

From the obtained results of metal to reagent ratio, and depending on thiazolylazo Compounds properties; the following structure can be suggested;

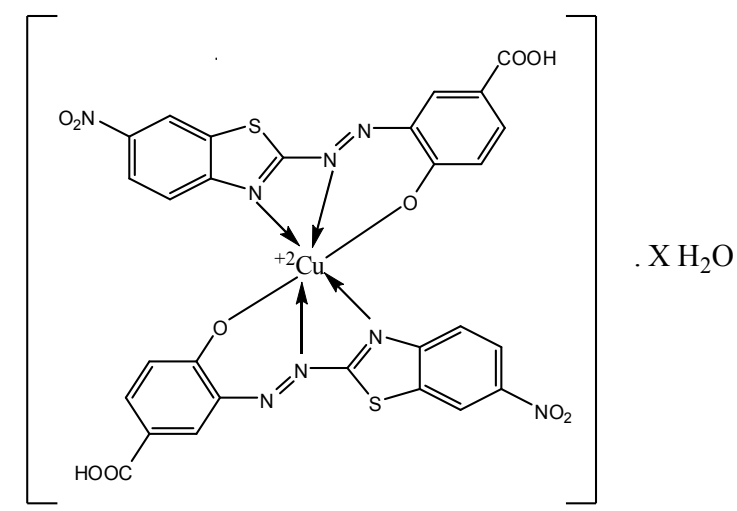

\section{Analytical Characteristics}

\section{Calibration curve}

Linear calibration graph through the origin was obtained which obeyed Beers law over the range (0.1-6.0) $\mu \mathrm{g} \cdot \mathrm{ml}^{-1}$ of $\mathrm{Cu}(\mathrm{II})$. The average molar absorptivity was found to be $\left(7.45 \times 10^{+3}\right)^{1} \cdot \mathrm{mol}^{-1} \cdot \mathrm{Cm}^{-1}$. The sandells sensitivity [19] was (0.0088) $\mu \mathrm{g}$ of $\mathrm{Cu}(\mathrm{II}) \cdot \mathrm{Cm}^{-2}$, and correlation coefficient (r) was 0.992 (Figure 10). 
Citation: Jreo AM (2015) Synthesis of the New 2-[6-Nitro-2-Benzothiazolylazo]-4-Hydroxy Benzoic Acid Organic Reagent for Spectrophotometric Determination of Copper(II). Biochem Anal Biochem 4: 167. doi:10.4172/2161-1009.1000167

Page 3 of 5

\begin{tabular}{|c|c|}
\hline Wave number $\left(\mathrm{Cm}^{-1}\right)$ & Groups \\
\hline $3300-3400$ & $\gamma \mathrm{O}-\mathrm{H}, \mathrm{H}_{2} \mathrm{OCrys}$. \\
\hline 2870 & $\gamma \mathrm{C}-\mathrm{H}$ Aliphatic \\
\hline 3020 & $\gamma \mathrm{C}-\mathrm{H}$ Aromatic \\
\hline 1740 & $\gamma \mathrm{C}=\mathrm{N}$ \\
\hline 1505 & $\gamma \mathrm{N}=\mathrm{N}$ \\
\hline 1422 & $\gamma \mathrm{C}=\mathrm{C}$ \\
\hline 1128 & $\gamma \mathrm{C}-\mathrm{S}$ \\
\hline 1280 & $\gamma \mathrm{C}-\mathrm{O}$ phenolic \\
\hline 1678 & $\gamma \mathrm{C}=\mathrm{O}$ carboxylic \\
\hline 1362 & $\gamma \mathrm{C}-\mathrm{N}$ \\
\hline
\end{tabular}

Table 1: Main vibration frequencies of main absorption bands characteristic of reagent.

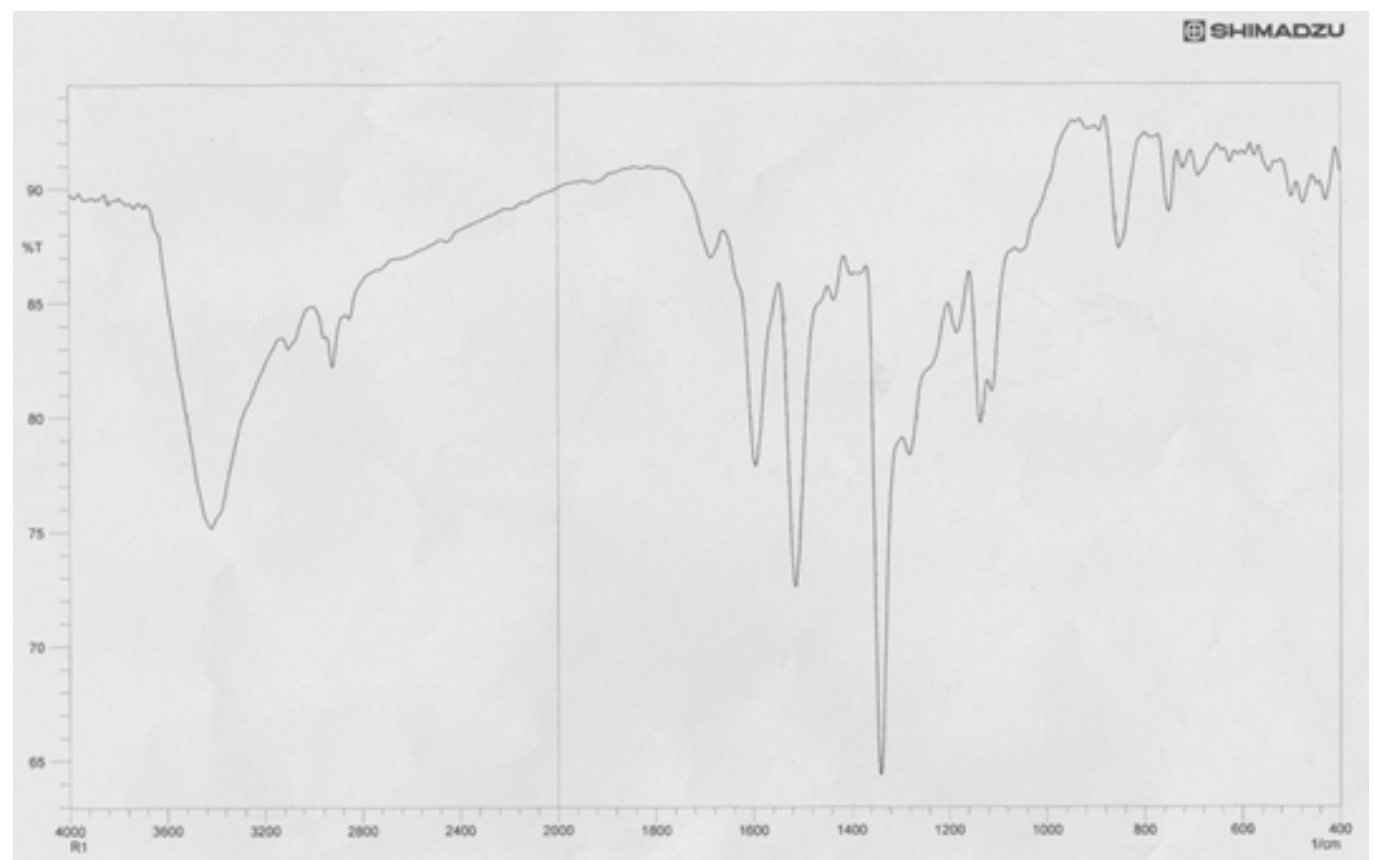

Figure 1: A typical sigmoid curve describing the kinetics of amyloid formation. The use of Equations (5)-(7) for analysis of the kinetics of protein fibrillation.

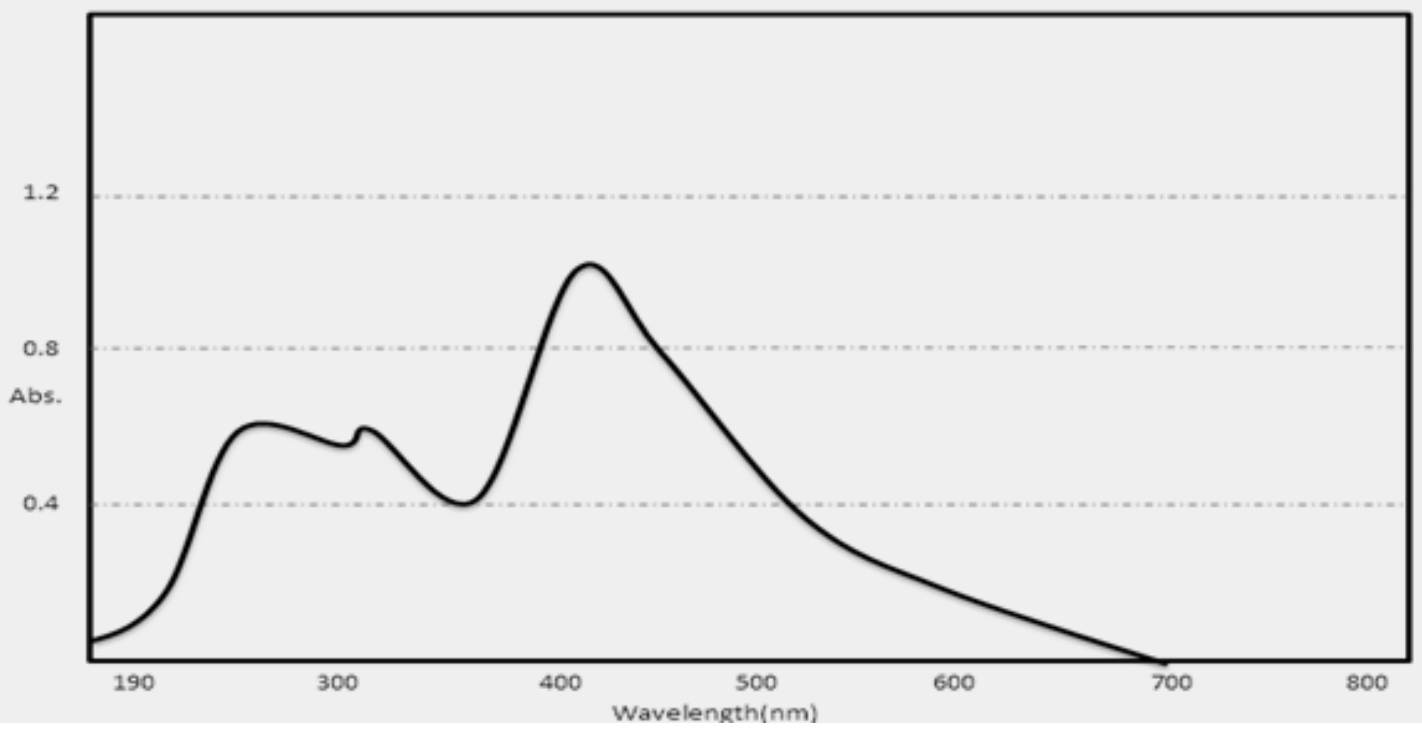

Figure 2: Uv-Visible spectrum of $\left(\mathrm{NO}_{2} \mathrm{BTAHB}\right)$ reagent. 


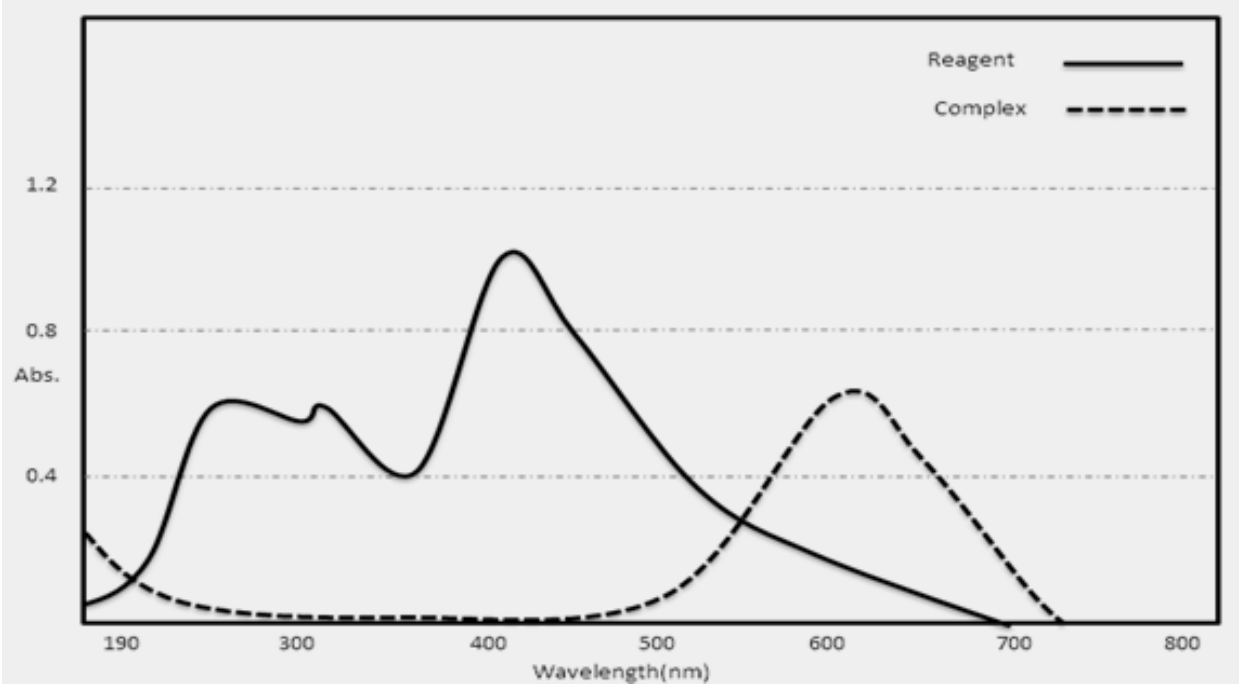

Figure 3: Uv-Visible spectrum of $\mathrm{Cu}(\mathrm{II})-\left(\mathrm{NO}_{2} \mathrm{BTAHB}\right)$ complex.

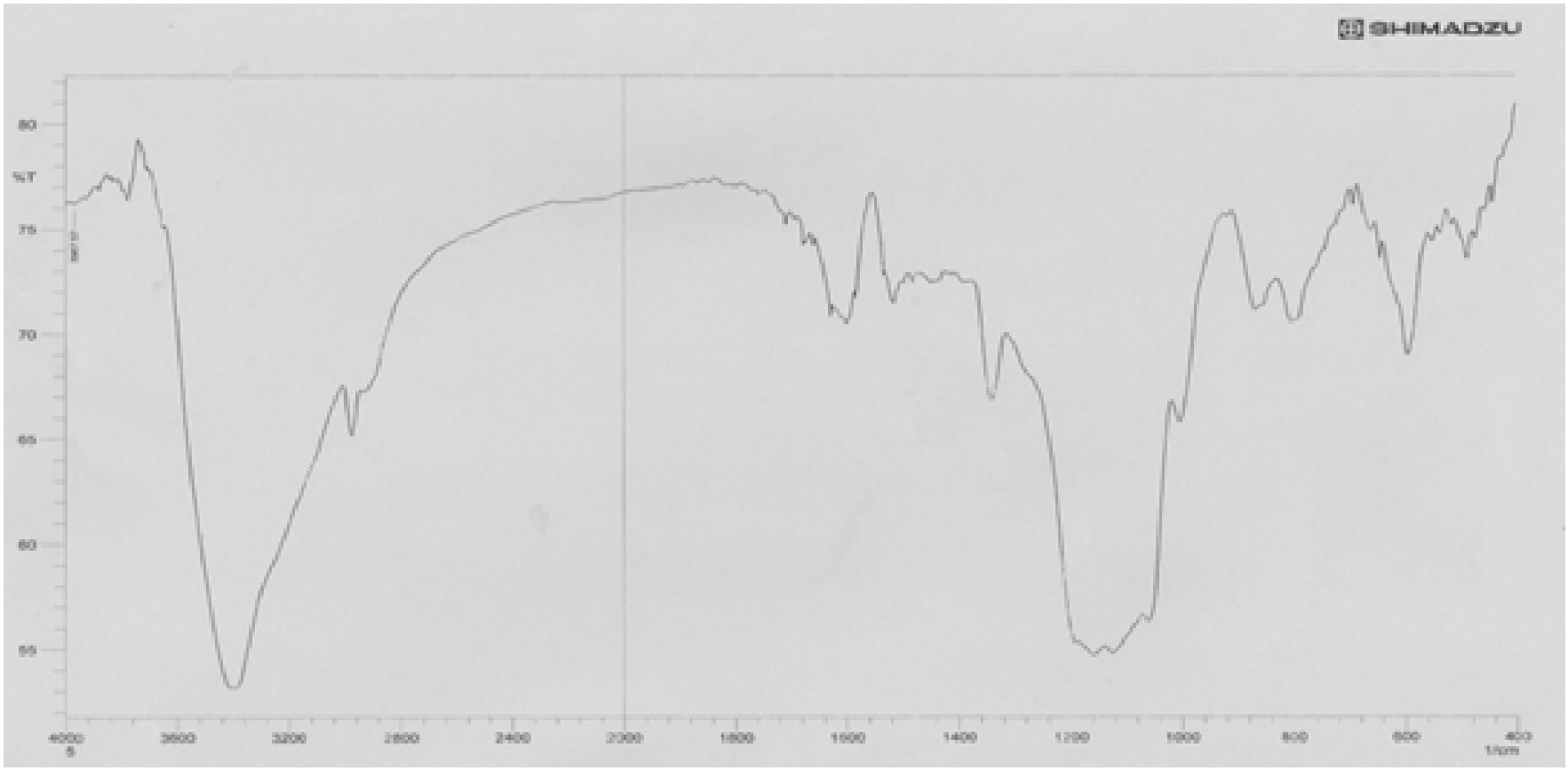

Figure 4: FT-IR spectrum of $\mathrm{Cu}(\mathrm{II})-\left(\mathrm{NO}_{2} \mathrm{BTAHB}\right)$ complex.

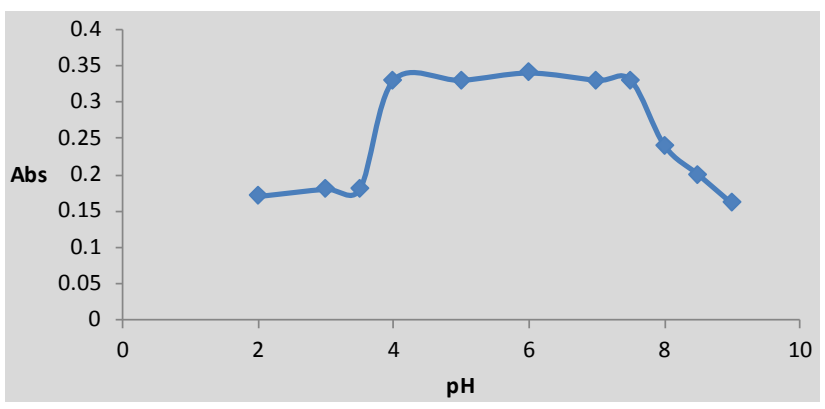

Figure 5: Effect of $\mathrm{pH}$ on absorbance $\mathrm{Cu}(\mathrm{II})-\left(\mathrm{NO}_{2} \mathrm{BTAHB}\right)$ complex.

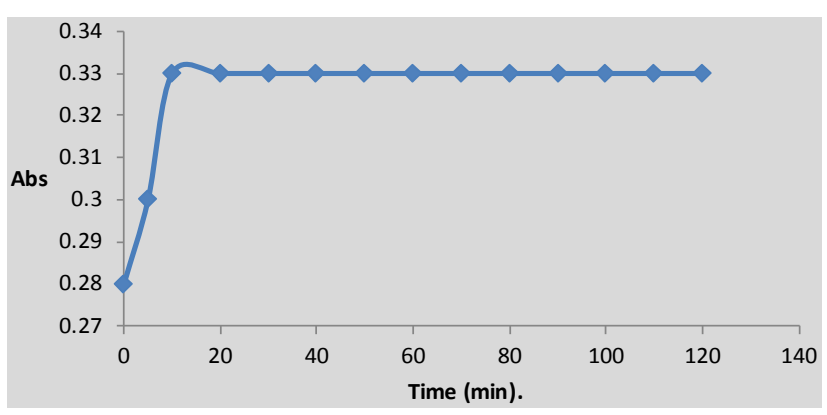

Figure 6: Effect of time on the stability of $\mathrm{Cu}(\mathrm{II})-\left(\mathrm{NO}_{2} \mathrm{BTAHB}\right)$ complex. 
Citation: Jreo AM (2015) Synthesis of the New 2-[6-Nitro-2-Benzothiazolylazo]-4-Hydroxy Benzoic Acid Organic Reagent for Spectrophotometric Determination of Copper(II). Biochem Anal Biochem 4: 167. doi:10.4172/2161-1009.1000167

Page 5 of 5

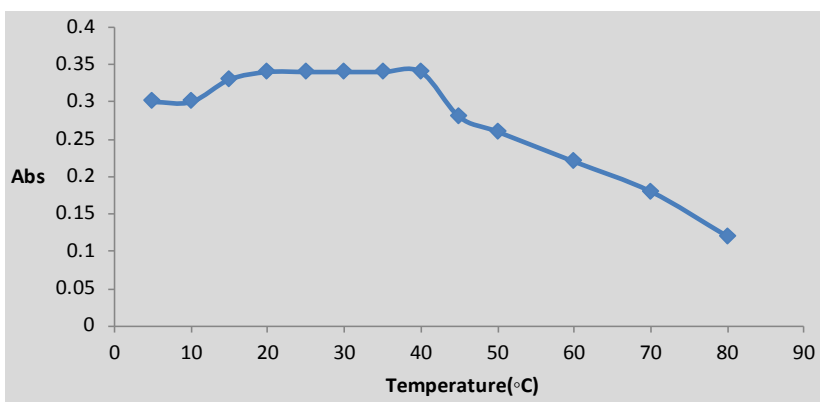

Figure 7: Effect of temperature on the stability of $\mathrm{Cu}(\mathrm{II})-\left(\mathrm{NO}_{2} \mathrm{BTAHB}\right)$ complex.

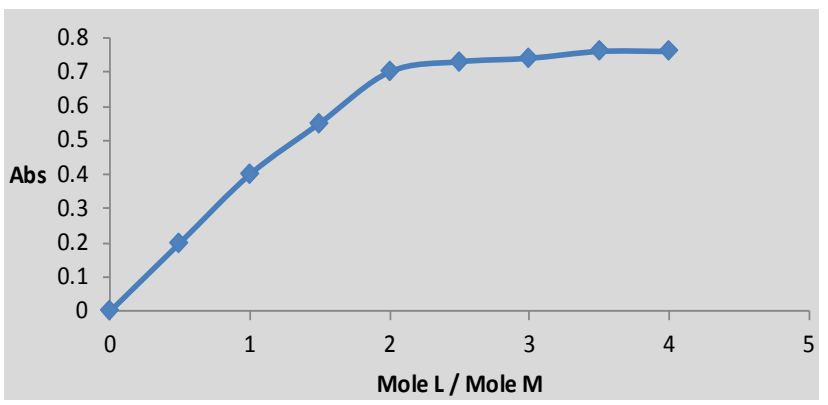

Figure 8: Mole ratio plot, $\mathrm{pH}=6.0$.

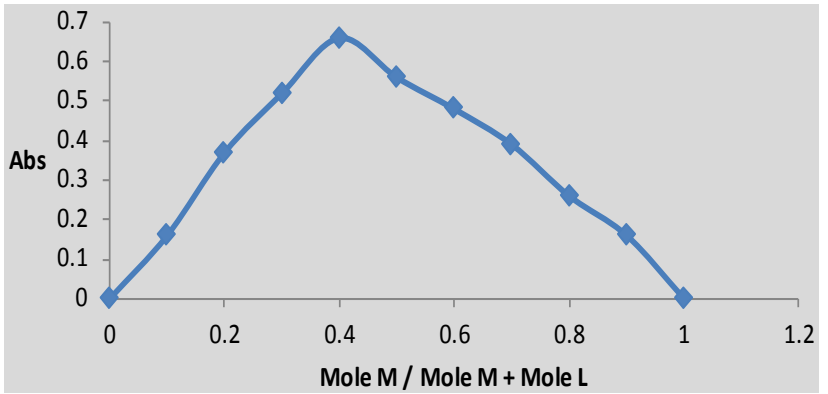

Figure 9: Jobs plot, $\mathrm{pH}=6.0$.

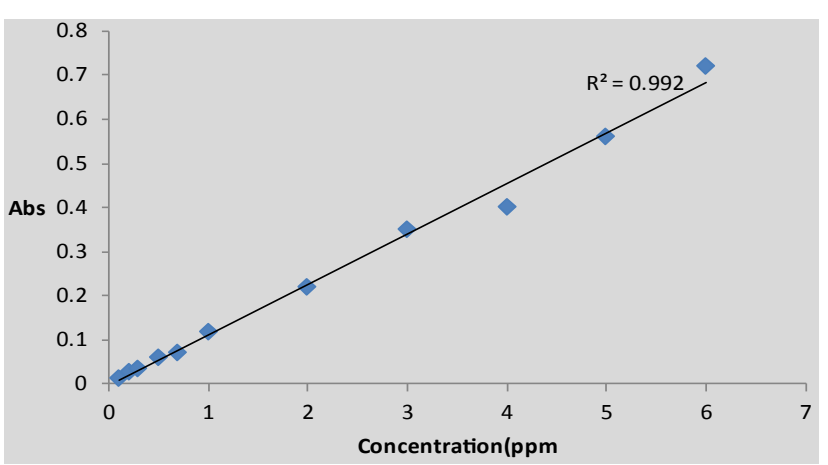

Figure 10: Calibration curve of $\mathrm{Cu}(\mathrm{II})-\left(\mathrm{NO}_{2} \mathrm{BTAHB}\right)$ complex.

\section{Precision and Accuracy}

The relative standard deviation (R.S.D\%), evaluated from seven independent determination of $3.0 \mu \mathrm{g} \cdot \mathrm{ml}^{-1}$ of $\mathrm{Cu}(\mathrm{II})$ was $1.7 \%$, this result show that this method is highly precise. Also the accuracy of this method was determined by calculated the Erel percentage for $3.0 \mu \mathrm{g} \cdot \mathrm{ml}^{-1}$ standard solution of $\mathrm{Cu}(\mathrm{II})$ which was found to be $(-1.4)$ and $\mathrm{Re} \%=98.6$.

\section{Interferences}

The effect of the ions $\left(\mathrm{Ni}^{2+}, \mathrm{CrO}^{2-}, \mathrm{Ca}^{2+}, \mathrm{pb}^{2+}, \mathrm{Cu}^{+2}, \mathrm{WO}_{4}^{-2}, \mathrm{MO}_{4}^{-2}\right.$, $\mathrm{Co}^{2+}, \mathrm{Mg}^{2+}, \mathrm{Cd}^{2+}, \mathrm{Ba}^{2+}, \mathrm{Bi}^{3+}$ ) which form complex with the reagent during its reaction with $\mathrm{Cu}(\mathrm{II})$ were studied. On the other hand, suitable masking agents examined for eliminating the effect of the twelve ions, where the mixture of $\mathrm{KI}, \mathrm{NaF}, \mathrm{Na}_{2} \mathrm{~S}_{2} \mathrm{O}_{3}$, and $\mathrm{DMG}$ were found to be a suitable masking agents.

\section{References}

1. Wen XD, Yang QL, Yan ZD, Deng QW (2011) Determination of cadmium and copper in water and food samples by dispersive liquid-liquid microextraction combined with UV-vis spectrophotometry. Microchem J 97: 249-254.

2. Ganjali MR, Aghabalazadeh S, Khoobi M, Ramazani A, Foroumadi A (2011) Nanocomposite Based Carbon Paste Electrode for Selective Analysis of Copper. Int J Electrochem Sci 6: 52-62.

3. Ghazy SE, El-Shazly RM, El-Shahawi MS, Al-Hazmi GAA, El-Asmy AA (2006) Spectrophotometric Determination of Copper (II) in Natural Waters, Vitamins and Certified Steel Scrap Samples Using Acetophenone-pchlorophenylthiosemicarbazone .J.Iranian Chemical Society 3: 140-150.

4. Lokhande RS, Kulkarni S, Pitale S, Patil SK, Janwadkar SP (2011) Extraction and Spectrophotometric Determination of $\mathrm{Cu}$ (II) Metal ions using Hydrazinecarboxymide2-[(2-hydroxyphenyl) methylene (HC22HPM) as an Analytical Reagent. International Journal of Pharma Sciences and Research (IJPSR) 2: 184-188.

5. Kavitha C, SarathBabu M, Saraswathi K (2013) Spectrophotometric determination of copper as copper Piperazine. International Letters of Chemistry, Physics and Astronomy 8: 205-209.

6. Turkoglu O, Soylak M (2005) Spectrophotometric Determination of Copper in Natural Waters and Pharmaceutical Samples with Chloro(phenyl) glyoxime. Journal of the Chinese Chemical Society 52: 575-579.

7. Jankiewicz B, Ptaszyński B, Turek A (1999) Spectrophotometric Determination of Copper (II) in Samples of Soil from Selected Allotment Gardens in Lodz 8: 35-38.

8. Ulusoy HI, Gurkan R, Akcay M (2011) Kinetic spectrophotometric determination of trace copper (II) ions by their catalytic effect on the reduction of brilliant cresyl blue by ascorbic acid. Turk J Chem 35: 599-612.

9. Sharma L, Rahman N, Azmi S, Iqbal B, Amburk MI, et al. (2010) UV Spectrophotometric determination of $\mathrm{Cu}$ (II) in Synthetic Mixture and Water Samples. Journal of the Chinese Chemical Society 57: 622-631.

10. Mouhsen Sh, Hassan K (2012) Iraqi National Journal of Chemistry 2: 281-292.

11. Triggle DJ (1996) Ion channels as pharmacologic receptors: the chirality of drug interactions. Chirality 8: 35-38.

12. Furukawa M, Katami T, Shibata S (1993) Spectrophotometric determination of copper in aluminium alloys using 2-[2-(4-methylbenzothiazolyl)azo]-5dimethylaminobenzoic acid. Journal of Analytical Chemistry 347: 462-464.

13. Shihad AA (2013) Preparation and Spectrophotometric Study of 2[2-(5-bromo thiazolyl) azo]-4-methoxy phenol.

14. Prodromidis MI, Stalkas CD, Veltsistas PT, Karayannis MI (1994) Spectrophotometric kinetic determination of copper (I1) trace amount s based on its catalytic effect on the reduction of the reduced 2,6-dichlorophenolindophenol and hydrogen peroxide. Talanta 41: 1645-1649.

15. Texeirra LSG, Costa ACS, Ferreira SLC, Carvalho CMS, Freitas ML (1999) Spectrophotometric deterimantion of uranium using 2-[2-thiazolyl) azo]-pcresol(TAC) in the presence of surfactants. J Braz Chem Soc 10: 519.

16. Gusev SI, Zhvakina MV, Kozhevnikov IA (1971) Thiazolylazo dyes and thei spectrophotometric applications in analytical chemistry. Zh Analit Khim 26: 859.

17. Vogel Al (1953) Macro and Semimicro Qualitative Inorganic Analysis 661.

18. Jop (1928) Formation and stability of inorganic complexes in solutions Ann. Chim 9: 113

19. Harvey AE, Manning DL (1950) Methods of establishing empirical formulas of colored complexes in solutions. J Am Chem Soc 72: 4488. 